\title{
The Evolving Parent: Outline of the Evolution of Parenting Styles
}

Received: January 29, 2019; Accepted: February 28, 2019; Published: March 08, 2019

\section{Introduction}

Parenting is one of the most difficult and important jobs, yet there is no official training and no schooling to prepare parents for what's to come. In this article I will highlight the needs for parent so constantly evolve and furthermore I will provide an outline illustrating a progression though Baumrind's parenting styles [1-3]. When we start off parenting, we need to show our kids right from wrong [4-7]. The outline starts with each parent exercising the authoritarian parenting style toward their children as in they are the parents and need to teach their children. I do not endorse exercising the harshness and withdrawn aspects of this particular parenting style, but I do think that the parent needs to show right from wrong with no explanation or choices because they are the parent. When cognitive development lends to understanding [8] parents show transition to the authoritative parenting style. At this point we explain, give choices and have firm consequences. Now that you have shown your kids what to do and explained why; it is time to let them really learn [9]. The learning portion of parenting calls for the permissive parenting style in that you as a parent let your kid make mistakes and learn from them. The instability portion of this original definition should not come into account because it is not what I am referring to in this part of parenting. Finally, parents need to back off and trust that they have effectively taught their children and evolve into the uninvolved parenting style. Parents should always be involved emotionally with their children, but they just need to give them space to live their lives and not continue to hover and fix everything from them. I would never claim to know the right answer for each child because every child is so different, but if we as parents would just follow this progression then maybe we can help produce successful young adults.

Most people have heard of the parenting styles and most parents buy one or two parenting books, each explaining that parents should be this kind or type of parent, but we usually all end up being different from "what we are supposed to be." Each parenting book describes different types of parenting styles and what can happen to your child if a parent to falls into one of the certain types [10]. There are often different names, but for the purposes of this argument for the evolving parent we will explore Baumrind's [1-3] classifications of parenting styles with modified definitions: the authoritarian, permissive, uninvolved, and the authoritative. The authoritarian parent is often described as the
Elizabeth Rodriquez*

Department of Psychology, Amarillo Community College, Amarillo, Texas, United States

\author{
*Corresponding author: \\ Dr. Elizabeth Rodriquez PhD. \\ झ eerodriguez@actx.edu; \\ e0316756@actx.edu
}
Department of Psychology, Amarillo Community College, Amarillo, Texas, United States.

TEL: (806)371-5192

Citation: Rodriquez E (2019) The Evolving Parent: Outline of the Evolution of Parenting Styles. J Child Dev Disord. Vol.5 No.1:3

military parent. "Do it because I said so" or "I am the parent so do what I say." Authoritarian style is also characterized as harsh and withdrawn. For this parenting outline, I do not recommend the harshness or being withdrawn, but I do believe it is important to state right and wrong as a parent. The permissive parent often seen as the "friend parent" or inconsistent, wanting the kid to like them so not ever really sticking to the what they say in the first place and then getting frustrated and punishing for things that they had rewarded once before. For my purposes, the permissive parenting style will be used as a learning experience in which the parent still has some control and can help if need be but this does allow the child to experience the situation even if we as parent know it is not a good decision. I usually explain the uninvolved or parent as the parent who likes the family pictures and the idea of a kid but does not what to put in the actual effort into raising a child. This type of parent will leave their kid with a babysitter, friends or family more often than taking care of the kid themselves. They have no emotional bond with their child with effects the attachment style and response to the parents [11]. I would never suggest that parents should not love their children, I do believe that parents do need to relinquish some control and back off so that their kids can become functioning adults. Finally, the all mighty authoritative. This is the style we all want to be, setting limits and forming rules with consequences that we always follow through with explaining to your kids along the way. Most research in parenting [12-16] highlights authoritative parenting as the most successful type of parenting. After being 
a parent to three wonderful, crazy and completely different children, I believe that we should not have one parenting style, but in truth, we should evolve through each of the parenting styles listed above. Hold on to your hats keep those books close, I want to explain.

Those first wonderful days when baby is born no one knows what they are doing. Parenting is not something that just happens, it takes time, training and practice. I have three kids and each time it was like starting over. You don't just know, but you have time to learn. So what do we do as parents? How do we make sure we prepare our kids so that they can be successful? I would not claim to know because I am still learning; however, I think that evolving through the parenting styles might give you a good outline on how to approach this important and difficult job. As parents grow, I think they learn how to deal with their kids and they learn that each kid is completely different. The trial and error method is most common and the second child often seems easier because you have been there and done that. Assuming that your second, third or even fourth kid will be just like your first is where most parents get themselves in trouble. Parent need to evolve, change and learn. As parents learn, it begins to make since why evolving through each parenting style might be the most successful.

The first is the authoritarian parent. There is and will always be some debate about whether or not we are born as a blank slate or some aspects of personality and/ morals are genetically passed on $[17,18]$. You as the parent need to be the one that tells your kids what is right from wrong. You are the role model, and at this age, children watch you and learn through observational learning [4-7]. Again I want to highlight the modified definition of this parenting style to make sure readers understand. For this outline the authoritarian parent tells their kids what is right and what is wrong because they are the parent. The main part that is excluded from the original explanations [1-3] is the idea of harsh behavior lacking warmth. Parents can be warm and loving while still explaining that something is right or wrong. At this point in their lives you are the one with more experience and it is your job to train them. You are the parent and you are the one who should know better. Small children do not understand the concepts that you try to explain even if you think it's a simple idea. Let's take "don't run into the street." Simple idea, super beneficial for your child to learn, but if you try to explain to them why, do they or would they really understand? At this point shouldn't we just tell them what not to do because we said so? I really believe that you need to set the path for you children and teaching them the right answer at this point in their life is the first step. That being said, parents should start off parenting as authoritarian in order to teach and show you children the building blocks of life.

Each child is different so age ranges do not apply. When your child reaches the age when they can understand and start asking questions, it is time to move on to the next parenting type. Now you should be the authoritative parents. The authoritative parent explains things, gives choices and sets clear limits with consequences for inappropriate actions. This seems to be the natural progression through teaching anyone how to think, how to solve problems and how to live. Once the foundation of what is expected and what is right or wrong is built, you can expand and explain further so that your kid can understand. To me it makes no sense to expect my child to know what it right or wrong unless I have explicitly told them. Now that they know, I can further explain and give options to let them show me that they do understand what I have told them. This stage of parent is probably the most difficult in that you have to be consistent and you have to follow through with your punishment and rewards. This takes extreme patience and willingness for parents to admit they have made mistakes. This stage is probably the most important as well. In order to make sure your child truly understands what you set forth in the beginning you need to explain why. Explaining why can be exhausting and you may have to do it a million times. You just keep explaining until they get it and that could be more times than your frustration level can handle. No one said it would be easy, but if you stay strong and build this moral foundation you are paving the way for your child to live a successful life [3,12-16].

Now when your kids look at you and explain what they did wrong before you even have to say anything then you get to move on to the next phase of parenting, permissive parenting. When I suggest permissive parenting, I am mainly highlighting the idea of saying one thing and then expecting another. This is so confusing but makes so much sense. Learning is the process acquiring new knowledge and understanding through experiences [9]. The most important part of this definition is through experience. I have told my children, I have explained to my children, but they have not necessarily experienced what I have told them, so have they really learned? This is where the permissive parenting comes in to play. Now that they know better you as a parent have to let them experience the consequences of their choices so that they can experience the lesson. Let's say for instance your kid wants to go hang out with a group of kids that you have told them about and warned them not to hang out with. Your kid asks if they can go and you might even remind them about your conversation. You let them hang out with these bad kids and nothing happens while your child is with them so now you ground them. What? That seems so wrong and you said they could go, but you are teaching them that they know better and will suffer the consequences. Let's say they go and this time something bad does happen; hopefully through experience your child has learned from their mistakes. This style of parenting should transpire when you can still help your child and the mistakes they make can be built on and learned from so that they can become functioning members of society.

As your children grow into adulthood there should be a natural progression in which you take your hands off the wheel and let them drive. This is the stage I will call the uninvolved parenting style. I realize that the definition of this style often highlights the idea of emotional detachment or not wanting to be involved. I do not think that is ever a part of parenting. What I think is important here is that you as a parent let your kids live. Because of the changing trends in how kids develop, there is a new term called emerging adulthood. Emerging adulthood describes the time from about the age of eighteen to around the age of twenty-five [19]. I believe that this term has come about because 
parents are too involved in their children's lives as their children are trying to establish their own lives. We are not teaching the same responsibilities and this makes them more reliant on their parents. I understand, that parents want to protect their kids and they want to give more than their parents gave them, but staying in their lives and controlling, or taking care of everything for them actually hinders their development. We need to back off and know that we have taught them right from wrong, we have explained why things are the way there are, and we have let them learn through experiences different aspects of life and now it is time to let them live.

\section{Conclusion}

Parenting is a difficult job and the worst part about it is you do not know if you have been successful until it is too late to change what you have done. The best part of parenting is that you

\section{References}

1 Baumrind D (1966) Effects of authoritative parental control on child behavior. Child Dev 37: 887 .

2 Baumrind D, Black A (1967) Socialization practices associates with dimensions of competence in preschool boys and girls. Child Dev 38: 291-327.

3 Baumrind D (1991) The influence of parenting style on adolescents competence and substance use. J Early Adolesc 11: 56-95.

4 Bandura A (1977) Social learning theory. Englewood Cliffs, NJ: Prentice Hall.

5 Bandura A (1986) Social foundations of thought and action: A social cognitive theory. Englewood Cliffs, NJ: Prentice Hall.

6 Bandura A (2007) Self-efficacy. In: International encyclopedia of organization studies (Clegg S, Bailey J Edn). Thousand Oaks, CA: Sage.

7 Flavell JH (1992) Cognitive development: Past, present and future. Dev Psychol 28: 998-1005.

8 Piaget J (1930) The child's conception of physical causality. London: Routledge \& Kegan Pail.

9 Myers D, DeWall C (2019) Exploring psychology (11 $1^{\text {th }}$ Edn). Worth Publishers, Inc.

10 Murkoff H, Mazel S, Widome M (2014) What to expect the first year. New York: Workman Publishing Company. are allowed to mess up and work each day to provide the best guidance you can for your children. The most important part is to always remember to involve love and understanding in your decisions. You should be evolving each day, each lesson and each time you encounter a new obstacle. Most research on parenting styles is self-report and being human we want to assume the best of ourselves and our parents as well as our own children. This lends to the validity of the self-report in our own parenting practices and our children to truly reflect on how we raised them. It would require some very insightful reflection and selfevaluation in which we all have trouble doing. It is possible that you move through each style in one day as new circumstances and stations arise in your child's life. I have just wanted to provide a short outline to explain how moving through each of the wellknown parenting styles might be a very effective way to raise a child and leave them with all the tools necessary to become a successful adult and loving parent for themselves.

11 Ainsworth MDS, Bell SM, Stayton DJ (1974) Infant-mother attachment and social development. In: The integration of a child into a social world (Richards MPM Edn). New York: Cambridge University Press.

12 Baldwin DR, Mclntyre A, Hardaway E (2007) Perceived parenting styles on college students' optimism. Coll Stud J 41: 550-557.

13 Gadeye WG, Ghesqure SR, Ongheria J (2004) Behavioral disinhibition and the development of substance-use disorders: findings from the Minnesota Twin Family Study. Dev Psychopathol 11: 869-900.

14 Maccoy EE, Martin JA (1983) Socialization in the context of the family: parent-child interaction. In: Handbook of Child Psychology (Mussen PH Edn). New York: Wiley 4: 1-101

15 Rauf K, Ahmed J (2017) The relationship of authoritarian parenting style and academic performance in school students. Pak J Psychol 48: 61-71.

16 Wood EE, Kennison SM (2017) Young children's risk-taking: mothers' authoritarian parenting predicts risk-taking by daughters but not sons. Child Dev Res 2017: 3719358.

17 Darwin C (1859) On the origin of species by means of natural selection. London: John Murray.

18 Skinner BF (1961) Teaching machines. Sci Am 205: 90-112.

19 Crandell T, Crandell T, Vander Zanden J (2012) Human development (10 ${ }^{\text {th }}$ Edn). New York: McGraw Hill. 